\title{
Az első onkológiai ellátás időfaktorának szerepe a daganatos betegségek túlélési mutatóiban
}

\author{
Irodalmi áttekintés
}

\author{
Mangel László dr. ${ }^{1}$ - Tornóczky Tamás dr. ${ }^{2}$ \\ Zemplényi Antal dr. ${ }^{3}$. Boncz Imre dr. ${ }^{3}$
}

Pécsi Tudományegyetem, Orvostudományi Kar, ${ }^{1}$ Klinikai Központ, Onkoterápiás Intézet, ${ }^{2}$ Klinikai Központ, Patológiai Intézet, ${ }^{3}$ Klinikai Központ, Pécs

\begin{abstract}
A szerzők célja a felnőttkori szolid tumoroknál a mútétre, illetve definitív onkológiai kezelésre való várakozás szerepének tisztázása volt. Ennek érdekében az orvosi szakirodalom áttekintésével, 67 retrospektív vizsgálat, illetve összefoglaló munka elemzésével felmérték az időfaktor, azaz a diagnózist követő kezelésindítás statisztikailag számszerüsíthető hatását a teljes túlélésre. Az időfaktornak biztosan komoly szerepe van a biológiailag agresszívebb betegségeknél, például fiatalkori emlő- és hereráknál vagy fej-nyaki tumoroknál, de az első onkológiai ellátás néhány napos és indokolt megkésése nem negatív hatású a legtöbb szolid daganatos betegségben. A kivizsgálás, illetve a kezelésindítás menetét több orvosi és pszichoszociális tényező alakíthatja, és sokszor éppen a legelőrehaladottabb kórképek ellátása történik meg korábban, inverz túlélési hatást eredményezve. Az onkológiai kezelések eredményességét alapvetően az optimális terápiaválasztás határozza meg, mindazonáltal az időfaktor szerepének megértéséhez feltétlenül további kutatások szükségesek.
\end{abstract}

Orv Hetil. 2018; 159(14): 535-546.

Kulcsszavak: onkológia, kezelés, időfaktor, túlélés

\section{The possible role of the timing of the first oncological treatment on the survival rate of cancer diseases}

\section{A literature overview}

The aim of this study was to survey the effects of the waiting time for the first oncology treatment in cancer diseases. By the analysis of 67 retrospective studies and reviews the numerical effects of treatment initiation time on survival were assessed. The "time factor" has a leading role on cancer types with aggressive biological behaviour, like breast cancer in younger age, testicular cancers, or head and neck tumours. However, a few days and reasonable delay to the first oncology intervention has no negative impact in numerous cancer diseases. The course of the primary check-up could be modified by several medical and psychosocial factors, and many times the treatment of the most advanced cancers are privileged causing an inverse survival effect. The effectiveness of the cancer therapies is determined by the optimal treatment decision, however, further research is necessary for the determination of the exact role of the "time factor" in oncology.

Keywords: oncology, treatment, timing, survival

Mangel L, Tornóczky T, Zemplényi A, Boncz I. [The possible role of the timing of the first oncological treatment on the survival rate of cancer diseases. A literature overview]. Orv Hetil. 2018; 159(14): 535-546.

(Beérkezett: 2017. augusztus 29.; elfogadva: 2018. január 16.)

Semmelweis Ignác születésének 200. évfordulója évében a Szerkesztőség felkérésére készített tanulmány. 
A daganatos betegeknél indikált különböző vizsgálatok és kezelések minél korábbi elvégzésének fontossága az utóbbi időben mind a szakma, mind a civil szféra érdeklődését felkeltette. Pár éve rendelet született arról, hogy daganatgyanús esetekben a komputertomográfiás (CT-) vizsgálatot kötelező 14 napon belül elvégezni [1], és ennek már mindenképpen pozitív hozadéka az, hogy jobban odafigyelünk az onkológiai betegekre. Azóta több fórumon is előkerült a kivizsgálások hatékony menedzselésének és a kezelések minél gyorsabban történő megindításának szükségessége [2], a még mindig igen szomorú hazai gyógyítási eredmények javításának a reményével [3]. Ez a kérdés azonban a szakmát is komoly dilemma elé állítja, hiszen a késés nélküli terápiaindítást sokszor nehezítik a mindennapos szervezési és kapacitásgondok és az a tény, hogy az optimálisnak vélt betegellátást számtalan fontos vizsgálat, konzultáció kell, hogy megelőzze. Például a közös terápiás orvosi megbeszélések, az „onkoteamek” mára már hozzátartoznak a betegellátás rutinmenetéhez. A kezelések optimalizálásának érthető célja mellett azonban az talán kevéssé ismert, hogy ahol jól múködik a közös döntési szisztéma, ott a betegek gyógyulási esélyei is egyértelműen javultak [4].

Az onkológiai kezelések jelentős részét a mütéti ellátás után végezzük el. Régóta ismert az a szakmai irányelv, hogy ezeket a beavatkozásokat időben, általában 2 hónapon belül szükséges megkezdeni. Az úgynevezett adjuváns onkológiai kezelések időfaktorának szerepe jól ismert, több tanulmány is bizonyítja az időben megkezdett sugárkezelésnek a helyi daganatmentességre és a kemoterápiának a távoli áttétképződés megelőzésére való egyértelmü hatását [5-7]. Az is biztos, hogy egy daganatos betegség első ellátásának megkezdésében a hosszú késlekedés végzetes következményekkel járhat. Ezt a gyakorló onkológusok a mindennapokban is látják, hiszen annál a betegnél, aki egyértelmü tünetek mellett hónapokig nem fordul orvoshoz, vagy aki a megajánlott kezelést nem fogadja el, ott a gyógyulási esélyek is sokkal rosszabbak. Kérdés azonban, hogy a kivizsgálás során elvesztett napok, esetleg hetek valóban és mindig végzetes következményekkel járnak-e, illetve az, hogy melyiknek komolyabb a hosszú távú hatása, a racionálisan végigvitt kivizsgálásnak, vagy a gyorsabb kezelésindításnak.

Az időfaktor szerepének megítélése nem egyszerü, és számba kell venni számtalan pszichoszociális tényezőt is. A jelen közleményünkben megpróbáltuk felmérni a szakirodalomban közölt eddigi ismereteket a kezelés kellő időben történő megkezdésének fontosságáról. Meg kell említeni, hogy hasonló széles körü áttekintést csak egyet találtunk az angol orvosi szakirodalomban [8], és ez magyar nyelven mindenképpen újdonságnak számít.

\section{Módszer}

Az időfaktor szerepének vizsgálata céljából áttekintettük a lektorált angol nyelvü orvosi szakirodalom talán leggyakrabban felkeresett internetes oldalán, a „PubMed”- en, illetve ellenőrzésként a „Scopus”-on és a „MeSH” keresőn fellelhető absztraktokat és közleményeket a "cancer treatment”, „waiting time" / "treatment delay” és „survival” kulcsszavak alapján. Az onkoterápia folyamatos fejlődését is szem előtt tartva keresési határként visszamenőlegesen a 2000-es évet jelöltük meg. Az egyes közlemények értelemszerűen és döntően az 5-15 évvel korábban kezelt betegek adatait dolgozták fel. Az irodalomgyưjitést 2017 júliusában zártuk le. A részletes elemzés során csak azokat a munkákat vettük figyelembe, amelyekben számszerüsítették az észleléseket, és a betegszám 300 feletti volt. Nem vizsgáltuk azokat a publikációkat, amelyek a harmadik világ legszegényebb vidékeiről származtak, és nem elemeztük a gyermekkori daganatok, az onkohematológiai kórképek és a transzplantációra váró májrákos betegek kezelésével kapcsolatos közleményeket. Nem vizsgáltuk az adjuváns kezelések időfaktorát sem, de ez utóbbi alól kivételnek tekintettük a malignus gliomákat, hiszen itt teljes mútéti radikalitásról alig beszélhetünk.

Az egyes közleményeket áttekintettük a hagyományos daganatcsoportosításnak (szervi kiindulás) megfelelően, illetve a különböző terápiás beavatkozások (sebészet, sugárterápia, primer gyógyszerterápia) függvényében. A kezelésre várakozás időtartamának a teljes túlélésre (illetve bizonyos esetekben a helyi daganatmentességre vagy éppen a biokémiai relapsus idejére) gyakorolt hatását elemezve kerestük a statisztikai összefüggések megadott paramétereit (p-érték, HR- [hazard ratio] és RR[relative risk] érték), illetve megfigyeltük a kiválasztott időhatárok és időintervallumok nagyságát, különbségeit. Értelemszerűen az összefoglaló közlemények kapcsán a statisztikai következtetéseket nem vártuk el. Ahol lehetett, a könnyebb áttekinthetőség céljából az adatokat táblázatba foglaltuk. Végül a diszkusszióban röviden öszszegeztük az esetleges pszichológiai és szociális szempontok szerepét is.

Itt meg kell említeni, hogy döntően retrospektív elemzések lelhetők fel a szakirodalomban, illetve néhány esetben más végpontokat kijelölő prospektív klinikai vizsgálatok részeként lehet az időfaktor szerepére adatokat találni.

\section{Eredmények}

\section{Emlörák (1. táblázat)}

McLaughlin rossz szociális körülmények között élő betegek esetében a szövettani diagnózistól mért 60 napon túli kezelésindítás hatását vizsgálta. Előrehaladott esetekben egyértelmúen károsnak ítélte meg a késlekedést, és 85\%-os emlőrák-specifikus mortalitásemelkedést észlelt. Ugyanakkor a korai emlőrák esetében ilyen összefüggést nem talált [9]. Smith 15 és 39 év közötti betegek adatait elemezve arra a következtetésre jutott, hogy a diagnózistól számított 2 héten belüli ellátás esetén 90\%os az 5 éves túlélési arány, 6 héten túli kezelésindítás ese- 
1. táblázat |Az emlőrák ellátásával foglalkozó közlemények

\begin{tabular}{|c|c|c|c|c|}
\hline Szerző, év és ország & Esetszám & $\begin{array}{l}\text { Vizsgált } \\
\text { időhatár }\end{array}$ & Túlélési hatás & Megjegyzés \\
\hline $\begin{array}{l}\text { McLaughlin, 2012, } \\
\text { USA }\end{array}$ & 1786 & 60 nap & $\begin{array}{l}\text { Van, OS; HR: } 1,66, \mathrm{p}=0,05, \\
\text { illetve DFS; HR: } 1,85, \mathrm{p}=0,04\end{array}$ & $\begin{array}{l}\text { Csak előrehaladott esetekben, korai emlőráknál } \\
\text { nincs különbség }\end{array}$ \\
\hline Smith, 2013, USA & 8860 & 2 hét, 6 hét & $\operatorname{Van}, \mathrm{p}=0,005$ & $\begin{array}{l}\text { Fiatal nőbetegeknél a } 2 \text { héten belüli terápia az } \\
\text { ideális }\end{array}$ \\
\hline $\begin{array}{l}\text { Redaniel, 2013, } \\
\text { Anglia }\end{array}$ & 53689 & $25,38,62$ nap & Nincs, HR: 1,06 & $\begin{array}{l}\text { Az } 5 \text { éves túlélési mutatók }(93 \%, 93,5 \%, 92,1 \%) \\
\text { hasonlóak }\end{array}$ \\
\hline $\begin{array}{l}\text { Eastman, } 2013 \text {, } \\
\text { USA }\end{array}$ & 301 & 46 nap & $\begin{array}{l}\text { Nincs, } \mathrm{p}=0,24, \mathrm{LR} ; \mathrm{p}=0,54 \\
\text { Van, } N S, \mathrm{p}=0,06\end{array}$ & $\begin{array}{l}\text { Tripla negatív emlőrák, nincs hatás sem lokális } \\
\text { kiújulásra, sem túlélésre, de } 90 \text { nap után már } \\
\text { negatív hatás }\end{array}$ \\
\hline $\begin{array}{l}\text { Souza, 2015, } \\
\text { Brazilia }\end{array}$ & 1299 & 60 nap & $\begin{array}{l}\text { Van, DFS; } \mathrm{p}=0,004 \\
\text { MET; } \mathrm{p}=0,038\end{array}$ & 60 év feletti nők, a teljes túlélést nem vizsgálták \\
\hline Shandiz, 2016, Irán & 452 & 15,25 nap & Nincs, $\mathrm{p}=0,676$ & $\begin{array}{l}\text { Korai emlőrák esetében } 2 \text { hét várakozás nem } \\
\text { káros hatású }\end{array}$ \\
\hline
\end{tabular}

DFS = (disease-free survival) betegségmentes túlélés; $\mathrm{LR}=$ lokális relapsus; MET = metasztázisképződés; NS = nem szignifikáns; OS = (overall survival $)$ teljes túlélés

2. táblázat | Malignus gliomák kezelésével foglalkozó közlemények

\begin{tabular}{|c|c|c|c|c|}
\hline $\begin{array}{l}\text { Szerző, évszám és } \\
\text { ország }\end{array}$ & Esetszám & $\begin{array}{l}\text { Vizsgált } \\
\text { időhatár }\end{array}$ & Túlélési hatás & Megjegyzés \\
\hline Lai, 2010, USA & 1375 & 3 hét & Nincs, $\mathrm{p}=0,14, \mathrm{HR}: 0,99$ & Idős, 65 év feletti betegek \\
\hline $\begin{array}{l}\text { Gliński, 2012, } \\
\text { Lengyelország }\end{array}$ & 308 & 37 nap & $\operatorname{Van}, \mathrm{p}=0,042$ & $\begin{array}{l}40 \text { év feletti betegeknél a } 2 \text { éves túlélők aránya } \\
\text { kisebb, késői kezelés esetén }\end{array}$ \\
\hline $\begin{array}{l}\text { Seidlitz, } 2015 \\
\text { Németország }\end{array}$ & 369 & 27 nap & $\operatorname{Nincs}(\mathrm{p}=0,705, \mathrm{HR}: 0,998)$ & RT- vagy RKT-kezelések esetén sem \\
\hline $\begin{array}{l}\text { Loureiro, } 2016, \\
\text { metaanalízis }\end{array}$ & 5212,12 tanulmány & Heti bontás & Nincs, HR: $0,98, \mathrm{p}=0,70$ & $\begin{array}{l}\text { RT-val ellátott betegek, elemzés heti bontás- } \\
\text { ban }\end{array}$ \\
\hline
\end{tabular}

$\mathrm{RKT}$ = radiokemoterápia; $\mathrm{RT}=$ radioterápia

tén pedig csak $80 \%$-os ez a mutató. Részletesen elemzik azt is, hogy az alacsony szociális státuszban lévők általában késve jutnak az ellátáshoz [10]. Redaniel a 2 hónapon belül operált betegeknél érdemi 5 éves túlélési különbséget nem észlelt [11]. Eastman magas rizikójú, úgynevezett tripla negatív emlőrákban sem észlelt túlélési hatást, de a 3 hónapon túl ellátott pácienseknél már élettartam-csökkenési tendenciát realizált [12]. Souza 60 év feletti betegeket vizsgálva megállapította, hogy a késlekedés mind a lokális, mind a távoli áttétképződés valószínüségét növeli [13]. Shandiz a mütéti ellátás kapcsán az időfaktor szerepét nem tudta bizonyítani, és 2 hetes késlekedést nem tartott végzetesnek [14].

\section{Malignus gliomák (2. táblázat)}

Lai 65 év feletti glioblastomás betegeknél megállapította, hogy a biopsziától vagy a reszekciótól eltelt több mint 3 hét várakozás nem érinti hátrányosan a túlélési mutatókat [15]. Gliński azt észlelte, hogy a későn (37 napon túl) megkezdett sugárkezelésnek negatív túlélési hatása van a 2 éves túlélők arányszámát illetően [16]. Seidlitz nem talált statisztikai összefüggést a kezelés megkezdése és a túlélési adatok között [17]. Loureiro metaanalízisében pedig több mint 5 ezer glioblastomás beteg adatait összegezte, és a sugárterápia megkezdésének idejét illetően nem talált összefüggést a túlélési mutatókkal [18].

\section{Fej-nyaki daganatok (3. táblázat)}

Chen közleményében [5] 20 relevánsnak ítélt vizsgálat metaanalízise kapcsán azt találta, hogy a sugárterápia megkezdésének egy-egy hónapos csúszása a lokális daganatmentesség szempontjából komoly rizikót hordoz, de a megkésett kezelés a teljes túlélési adatokban csak marginális romlást hozott. Fortin korai gégészeti daganatok sugárkezelésének 30 napon túli megkezdését mind a lokális kontroll, mind a teljes túlélés szempontjából negatív hatásúnak véleményezte [19]. Caudell előrehaladott tumorok sugárkezelése után nem észlelt időhatást sem a lokális kontrollban, sem az áttétképződésben, sem a teljes túlélésben [20]. Van Harten komplex hollandiai fel- 
3. táblázat |A fej-nyaki tumorok ellátásával foglalkozó közlemények

\begin{tabular}{|c|c|c|c|c|}
\hline Szerző, évszám és ország & Esetszám & Vizsgált időhatár & Túlélési hatás & Megjegyzés \\
\hline Fortin, 2002, Kanada & 623 & 30,40 nap & Van, HR: 1,7 & RT konzílium idejéhez mérten \\
\hline Chen, 2008, metaanalízis & 4 tanulmány & Havi bontás & NS, RR: 1,16 & RT, lokális relapsus kockázata; RR: 1,15 \\
\hline Caudell, 2011, USA & 427 & 34 nap & Nincs, $\mathrm{p}=0,32$ és $\mathrm{p}=0,07$ & $\begin{array}{l}\text { RT elörehaladott esetekben, nincs hatás } \\
\text { lokálkontrollra vagy túlélésre }\end{array}$ \\
\hline $\begin{array}{l}\text { van Harten, 2014, } \\
\text { Hollandia }\end{array}$ & 2493 & 30 nap & $\begin{array}{l}\text { Nincs, inverz, HR: } 0,838 \text { és } \\
0,816\end{array}$ & $\begin{array}{l}\text { Egyik daganatspecifikus túlélési mutató sem } \\
\text { változott } 90 \text { napig }\end{array}$ \\
\hline $\begin{array}{l}\text { van Harten, 2015, } \\
\text { Hollandia }\end{array}$ & 13140 & 37 nap & $\operatorname{Van}, \mathrm{p}<0,0001$ & $\begin{array}{l}\text { A hosszabb távon várakozók szociálisan rossz } \\
\text { státuszúak }\end{array}$ \\
\hline Murphy, 2016, USA & 51655 & 52,67 nap & $\operatorname{Van}, \mathrm{p}=0,001$ & $\begin{array}{l}\text { Igen jelentős medián túlélési különbségek } \\
(71,9,61,46,6 \text { hó })\end{array}$ \\
\hline Sharma, 2016, USA & 6606 & 30 nap & $\operatorname{Van}, \mathrm{p}=0,005, \mathrm{HR}: 1,12$ & $\begin{array}{l}\text { Minden hét csúszás 2,2\% mortalitásemelkedés- } \\
\text { sel jár }\end{array}$ \\
\hline Liao, 2017, Tajvan & 18677 & $20,45,90$ nap & Van, HR: 1,$28 ; 1,25 ; 1,07$ & $\begin{array}{l}\text { Szájüregi tumorok, 90\%-ban } 45 \text { napon belüli } \\
\text { ellátás }\end{array}$ \\
\hline Cheraglou, 2017, USA & 5627 & 100 nap & $\begin{array}{l}\text { Van, HR: } 1,605 \\
\mathrm{p}=0,006\end{array}$ & $\begin{array}{l}\text { Korai gégerák, specializált centrumokban jobb } \\
\text { eredmények }\end{array}$ \\
\hline $\begin{array}{l}\text { Polesel, 2017, Olaszor- } \\
\text { szág }\end{array}$ & 1616 & $\begin{array}{l}\text { 13-45, illetve } \\
>90 \text { nap }\end{array}$ & Van, HR: 1,$13 ; 1,47, \mathrm{p}<0,0001$ & $\begin{array}{l}\text { Komolyabb különbség korai FNYS-, illetve } \\
\text { gégerákoknál }\end{array}$ \\
\hline Liang, 2017, Kína & 9896 & $30,60,90$ nap & Van, HR: $1,13, \mathrm{p}=0,003$ & $\begin{array}{l}\text { Orrgarattumor, egyértelmú betegségkontroll } \\
\text { és túlélési hozadék }\end{array}$ \\
\hline
\end{tabular}

NS = nem szignifikáns; $\mathrm{RT}=$ radioterápia

4. táblázat | Tüdőrák ellátásával foglalkozó közlemények

\begin{tabular}{|c|c|c|c|c|}
\hline $\begin{array}{l}\text { Szerző, évszám és } \\
\text { ország }\end{array}$ & Esetszám & Vizsgált időhatár & Túlélési hatás & Megjegyzés \\
\hline $\begin{array}{l}\text { Myrdal, } 2004, \\
\text { Svédország }\end{array}$ & 466 & 4 hónap & $\begin{array}{l}\text { Nincs, inverz hatás, } \\
\text { RR: } 0,98\end{array}$ & $\begin{array}{l}\text { Az előrehaladott stádiumú betegek ellátása korábban } \\
\text { kezdődik meg }\end{array}$ \\
\hline Yorio, 2009, USA & 482 & 45,76 nap & Nincs, $\mathrm{p}=0,42$ & Magán-, illetve közkórházak között komoly különbség \\
\hline $\begin{array}{l}\text { Diaconescu, } 2011 \text {, } \\
\text { Kanada }\end{array}$ & 495 & 73 nap & Nincs, inverz, $\mathrm{p}=0,027$ & $\begin{array}{l}\text { A gyorsan kezelt (és elörehaladott állapotú) betegek } \\
\text { túlélési esélyei rosszabbak }\end{array}$ \\
\hline $\begin{array}{l}\text { Radzikowska, 2012, } \\
\text { Lengyelország }\end{array}$ & $8705+1881$ & 120 nap & $\begin{array}{l}\text { Nincs, HR: } 1,14 \\
\mathrm{p}=0,001 \\
\text { Van, HR: } 0,88 \\
\mathrm{p}=0,001\end{array}$ & $\begin{array}{l}\text { A késői orvoshoz fordulás rontotta az esélyeket, az } \\
\text { elhúzódó ellátás nem }\end{array}$ \\
\hline Samson, 2015, USA & 27022 & 8 hét & $\begin{array}{l}\operatorname{Van}, \mathrm{p}<0,001 \\
\text { NS (MVA) }\end{array}$ & $\begin{array}{l}\text { Korai tüdőrák, megkésett mútét szociálisan elesettebb } \\
\text { betegeknél }\end{array}$ \\
\hline Gomez, 2015, USA & 28732 & 27 nap & Van, korai esetekben & $\begin{array}{l}\text { Hatás jobb prognózisú esetekben, a PET időveszteséggel } \\
\text { járhat }\end{array}$ \\
\hline $\begin{array}{l}\text { Vinod, } 2017, \\
\text { Ausztrália }\end{array}$ & 1926 & 32 nap & Nincs, inverz, HR: 0,99 & $\begin{array}{l}\text { I-II. stádium esetén nincs hatás, III-IV. stádium esetén } \\
\text { inverz hatás, } p=0,0008\end{array}$ \\
\hline
\end{tabular}

MVA = multivariációs analízis; NS = nem szignifikáns; PET = pozitronemissziós tomográfia

mérése szerint a hosszabb várakozási idő szignifikánsan rontja a túlélési esélyeket. A diszkusszió jelezte, hogy a hosszabban várakozók között több volt a rossz szociális körülmények között élő, előrehaladott daganattal rendelkező, csak sugárkezelésre alkalmas beteg [21]. Érdekes módon egy korábbi közleménye nem talált szignifikáns összefüggést a megkésett ellátást és a daganatspecifikus túlélést illetően, sőt inverz túlélési hatást jelzett [22]. Murphy az Egyesült Államok betegbiztosí- tójának adatbázisából való adatokat összesítette, és igen jelentős különbségeket tudott kimutatni a túlélési mutatókban a kezelés megkezdésének ideje szerint [23]. Sharma szintén megállapította, hogy elörehaladott tumorok esetében minden hét késlekedés mortalitásnövekedéssel jár együtt, persze a szociális faktoroknak igen komoly a szerepük [24]. Liao szájüregi tumoros betegeknél 4 időcsoportot hozott létre, és azt észlelte, hogy a 20 napon belüli kezelésindításhoz képest a többi be- 
tegcsoport túlélési adatai szignifikánsan rosszabbak voltak [25]. Cheraghlou szerint korai gégeráknál a 100 napon túli ellátás a túlélés esélyének szignifikáns csökkenését okozza [26]. Polesel 30 napon belüli terápiaindításnál 62\%-os, 90 nap után csak 39\%-os 5 éves túlélést regisztrált [27], de azt is leírta, hogy a felkészültebb, innovatív terápiát felhasználó centrumok gyógyítási eredményei sokkal jobbak (HR: 0,73). Liang orrgarattumorok sugárkezelése kapcsán megállapította, hogy a 30 napon túli kezelésindításnak egyértelmúen hátrányos hatása van a túlélési mutatókra [28].

\section{Nem kissejtes tüdőrák (4. táblázat)}

Myrdal arra a paradox megállapításra jutott, hogy a kezelésre való hosszabb várakozás esetén jobbak a túlélési mutatók, pedig az átlagos várakozási idő elérte a 4-5 hónapot is. Ezt azzal magyarázta, hogy az előrehaladott állapotú, tünetes betegek kezelése általában előbb kezdōdik meg [29]. Yorio a radiológiai gyanúhoz mért diagnózis és terápiaindítás idejét vizsgálva negatív túlélési hozadékot szintén nem talált [30]. Diaconescu csak az előrehaladott eseteket illetően talált időbeli összefüggést, az elvártaktól eltérôen azonban a gyorsan kivizsgált és (kemoterápiával) kezelt betegek túlélési mutatói sokkal rosszabbak voltak, közel feleolyan hosszú átlagos túléléssel (6,8 versus 11,6 hónap) [31]. Radzikowska azt észlelte, hogy a betegek késői orvoshoz fordulása egyértelmú- en rontotta a túlélési esélyeket, ugyanakkor az elhúzódó orvosi kivizsgálásnak nem volt negatív hatása [32]. Samson az Egyesült Államok onkológiai adatbázisából megállapította, hogy operábilis tüdőráknál a megkésett mütét előrehaladottabb esetekben, alacsonyabb szociális státuszban élőknél fordult inkább elő. Mindez az élettartam csökkenését is okozta (medián túlélési idők 69,2 és 57,7 hónap), de a multivariációs analízis nem bizonyította a statisztikai különbséget [33]. Gomez azt bizonyította, hogy a 27 napon túli kivizsgálás bizonyos betegcsoportokban (korai stádium, jó prognózis) túlélési hátránnyal jár [34]. Vinod különböző terápiás modalitásokkal ellátott betegeknél nem tudta igazolni az időfaktor szerepét, sőt előrehaladott esetekben inverz hatással számolt [35].

\section{Emésztôszervi daganatok (5. táblázat), nyelöcsörák és gyomorrák}

Visser szerint elsődleges mütéttel vagy neoadjuváns radiokemoterápiás kezeléssel ellátott nyelőcsőrákos pácienseknél a 8 héten belül vagy azon túl megkezdett primer ellátás nincs hatással sem a betegségmentes, sem a teljes túlélési mutatókra. Egy másik, teljes hollandiai felmérésében szintén azt észlelte, miszerint a várakozási idő nem befolyásolta a túlélési időket, sőt a hosszabb várakozás nem érintette a mútéti radikalitást vagy a stádiumbeosztást sem [36, 37]. Brenkman gyomortumoros betegek adatbázisát áttekintve azt jelezte, hogy az 5 , illetve 8

5. táblázat | Emésztőszervi daganatok ellátásával foglalkozó közlemények

\begin{tabular}{|c|c|c|c|c|}
\hline $\begin{array}{l}\text { Szerző, évszám és } \\
\text { ország }\end{array}$ & Esetszám & $\begin{array}{l}\text { Vizsgált } \\
\text { időhatár }\end{array}$ & Túlélési hatás & Megjegyzés \\
\hline $\begin{array}{l}\text { Visser, 2016, } \\
\text { Hollandia }\end{array}$ & 351 & 8 hét & $\begin{array}{l}\text { Nincs, } \\
\mathrm{p}=0,374 \text { és } \mathrm{p}=0,693\end{array}$ & $\begin{array}{l}\text { Nyelőcsőrák, sem műtétnél, sem RKT-nál nincs DFS-, } \\
\text { OS-különbség }\end{array}$ \\
\hline $\begin{array}{l}\text { Visser, 2016, } \\
\text { Hollandia }\end{array}$ & 3839 & $\begin{array}{l}5 \text { hét, } \\
8 \text { hét }\end{array}$ & $\begin{array}{l}\text { Nincs, HR: } 0,92,1,00 \\
\mathrm{p}=0,432,0,973, \text { illetve } \\
\text { HR: } 1,12,1,21 \\
\mathrm{p}=0,171,0,167\end{array}$ & $\begin{array}{l}\text { Nyelőcsőrák, sem mütétnél, sem RKT esetén nincs túlélési } \\
\text { hatás }\end{array}$ \\
\hline $\begin{array}{l}\text { Brenkman, 2017, } \\
\text { Hollandia }\end{array}$ & 3778 & $\begin{array}{l}5 \text { hét, } \\
8 \text { hét }\end{array}$ & $\begin{array}{l}\text { Nincs, HR: } 0,82-0,85 \\
\text { és } 0,91-0,92\end{array}$ & $\begin{array}{l}\text { Gyomortumor, sem neoadjuváns } \mathrm{KT} \text {, sem primer műtét } \\
\text { esetén nincs időhatás }\end{array}$ \\
\hline Raptis, 2010, Anglia & 355 & 2 hónap & Nincs, $\mathrm{p}=0,134$ & Pancreasrák, a várakozás nem befolyásolta a reszekabilitást \\
\hline Amr, 2016, Anglia & $388(71)$ & 35 nap & $\begin{array}{l}\text { Nincs, inverz hatás } \\
(\mathrm{p}=0,041)\end{array}$ & Pancreasrégió-rákok, inverz hatás periampullaris rákoknál \\
\hline Gort, 2010, Hollandia & 819 & Több időhatár & $\begin{array}{l}\text { Van, DFS, } \mathrm{p}=0,018 \\
\mathrm{OS}, \mathrm{p}=0,048\end{array}$ & $\begin{array}{l}\text { Csak I-III. stádiumú rectumtumorok, hatás mind } \\
\text { DFS-ben, mind relatív túlélésben }\end{array}$ \\
\hline Helewa, 2013, Kanada & 1628 & 95 nap & Nincs, $\mathrm{p}=0,4898$ & $\begin{array}{l}\text { CRC I-IV., rapid tünetképzés, a rossz szociális státusz } \\
\text { hátrányt jelent }\end{array}$ \\
\hline Amri, 2014, USA & 769 & 4 időszak & $\begin{array}{l}\text { Nincs, inverz, } \\
\text { HR: } 0,81, \mathrm{p}=0,001\end{array}$ & $\begin{array}{l}\text { CRC, az elörehaladott esetek sokszor előbb kerülnek } \\
\text { mútétre, az MVA negatív }\end{array}$ \\
\hline $\begin{array}{l}\text { Redaniel, 2014, } \\
\text { Anglia }\end{array}$ & 46511 & $25,38,62$ nap & Változó, HR: 1,5; 1,16 & $\begin{array}{l}\text { CRC, a nagyon korai és a késői műtét fokozott mortalitás- } \\
\text { sal jár }\end{array}$ \\
\hline Murchie, 2014, Skócia & 958 & 4, 34 hét & Nincs, HR: 0,99 & CRC, az ellátás minősége a fontos, nem az időfaktor \\
\hline
\end{tabular}

$\mathrm{CRC}=$ colorectalis carcinoma; DFS = (disease-free survival $)$ betegségmentes túlélés; $\mathrm{KT}=$ kemoterápia; MVA = multivariációs analízis; OS = (overall survival $)$ teljes túlélés; RKT = radiokemoterápia 
héten túli ellátásindítás sem neoadjuváns kemoterápia, sem primer mútét esetén nem érintette hátrányosan a gyógyulási eredményeket [38].

\section{Hasnyálmirigy-carcinoma}

Raptis mütéti ellátás kapcsán megállapította, hogy a hosszabb várakozási idő nem befolyásolta sem a reszekabilitást, sem a teljes túlélési mutatókat [39]. Amr pancreas környéki rákok esetében érdekes módon azt tapasztalta, hogy periampullaris daganatoknál a hosszabb várakozási idő előnyösebb volt a túlélési mutatók szempontjából (38,3 versus 27,5 hónap). Ezt a paradox jelenséget a később operált páciensek agresszívebb onkológiai kezelésével próbálta magyarázni [40].

\section{Colorectalis carcinoma}

Gort kizárólagosan végbélcarcinomák eseteit vizsgálva az időfaktor szignifikáns hatását észlelte a túlélési mutatókra [41]. Helewa mütéttel ellátott betegeknél az időfaktor és a túlélési mutatók között nem talált összefüggést [42]. Amri fordított hatást állapított meg, a korábban operált betegek túlélési esélyei rosszabbak voltak, hiszen az előrehaladottabb esetek sokszor hamarabb kerültek ellátásra [43]. Redaniel érdekes, U alakú túlélési effektust detektált: a nagyon korán, illetve a későn mütött betegek túlélési mutatói voltak rosszabbak [44]. Murchie skóciai adatfeldolgozása panaszos betegeknél nem talált összefüggést az ellátás ideje és a túlélési mutatók között, és a szakszerûség fontosságát hangsúlyozta [45].

\section{Urológiai daganatok, prostatacarcinoma (6. táblázat)}

Dülmirigyrákok esetében sok szerző nem a teljes túlélést, hanem a PSA-relapsus idejét vizsgálta. Nguyen alacsony rizikó esetén nem, magas rizikó esetén talált biokémiai hatást a sugárterápia megkezdésével kapcsolatban [46]. Graefen radikális prostatectomiával ellátott betegeknél nem talált összefüggést a várakozás és a túlélési mutatók között [47]. Andrews a kezelés megkezdésének idejét 3 hónapos klaszterekre osztotta, és így a 9 hónapon túli ellátás sem rontotta a túlélési (biokémiai relapsus, távoli áttétek megjelenése) mutatókat [48]. O’Brien alacsony rizikójú betegeknél talált, Korets egyik kockázati csoportot illetően sem talált összefüggést a megkésett mútéti ellátás és a biokémiai relapsus között; az utóbbi felmérésnél valamennyi „időcsoportban” 78-85\% közötti 5 éves túlélést írtak le $[49,50]$. Van den Bergh irodalmi áttekintése szerint alacsony rizikójú betegség esetén nem számít az időfaktor, közepes és magas rizikó esetén pedig további vizsgálatok szükségesek [51]. A várakozás negatív hatását 17 értékelhető vizsgálatból 4 vizsgálatnál realizálta, és érdekes módon 2 közleményben éppen alacsony rizikójú betegeknél. Redaniel nem talált túlélési különbséget a mütét ideje alapján [52]. O'Callaghan a várakozási idő szerint 4 csoportra osztotta a betegeket, és nem észlelt összefüggést a megkésett kezelés és a prosztataspecifikus túlélési kockázat között, de azt is jelezte, hogy a korán megkezdett kezelések esetében több volt a magas rizikójú beteg [53].

6. táblázat | Prostatarák ellátásával foglalkozó közlemények

\begin{tabular}{|c|c|c|c|c|}
\hline Szerző, évszám és ország & Esetszám & Vizsgált időhatár & Túlélési (PSA-relapsus-) hatás & Megjegyzés \\
\hline Nguyen, 2005, USA & 460 & 2,5 hó & $\begin{array}{l}\text { Van, } \mathrm{p}=0,029 \\
\text { Nincs, } \mathrm{p}=0,31\end{array}$ & $\begin{array}{l}\text { RT, a késés magas rizikónál hátrányos, alacsonynál } \\
\text { nem }\end{array}$ \\
\hline $\begin{array}{l}\text { Graefen, 2005, Német- } \\
\text { ország }\end{array}$ & 795 & 62 nap & Nincs, $\mathrm{p}=0,841$ & $\begin{array}{l}\text { Mütét, magas rizikónál sem volt fokozott } \\
\text { kockázat }\end{array}$ \\
\hline Andrews, 2005, USA & 1322 & $\begin{array}{l}\text { 3-6-9 hó } \\
(3,3 \text { hó })\end{array}$ & $\begin{array}{l}\text { Nincs, } \mathrm{p}=0,5593,0,4642 \\
\text { HR: } 0,003\end{array}$ & $\begin{array}{l}\text { RT, nincs hatás sem biokémiai relapsusra, sem } \\
\text { távoli áttétekre }\end{array}$ \\
\hline O’Brien, 2011, USA & 1111 & 6 hónap & $\operatorname{Van}, \mathrm{p}=0,04$ & $\begin{array}{l}\text { Mütött alacsony rizikójú betegek, PSA-relapsus- } \\
\text { hatás }\end{array}$ \\
\hline Korets, 2012, USA & 2739 & 6, 9 hónap & Nincs, $\mathrm{p}=0,11$ & $\begin{array}{l}\text { Operált betegek, nincs hatás PSA-relapsusra és } \\
\text { túlélésre }\end{array}$ \\
\hline $\begin{array}{l}\text { van den Bergh, 2013, } \\
\text { review }\end{array}$ & $\begin{array}{l}34517, \\
17 \text { tanulmány }\end{array}$ & Akár 9 hónapig & Van: $4 / 17$, Nincs: $13 / 17$ & További vizsgálatok szükségesek \\
\hline Redaniel, 2013, Anglia & 17043 & 3, 6 hó & $\begin{array}{l}\text { Nincs, RR: 1,04-1,05, } \\
\text { illetve } 1,07-1,08\end{array}$ & $\begin{array}{l}\text { Mütét } 6 \text { hónapon belül, } 5 \text { és } 10 \text { év alatt nincs } \\
\text { különbség }\end{array}$ \\
\hline $\begin{array}{l}\text { O’Callaghan, } 2017 \text {, } \\
\text { Ausztrália }\end{array}$ & 3140 & $\begin{array}{l}35-86-138-264 \\
\text { nap }\end{array}$ & $\begin{array}{l}\text { Nincs, HR: } 4,37,1,29 \\
1,55\end{array}$ & Magas rizikó esetén általában korábbi kezdés \\
\hline Saad, 2006, review & 13 tanulmány & 244 napig & Van: $6 / 13$, Nincs: $7 / 13$ & $\begin{array}{l}\text { PSA-relapsus-kockázat extrém hosszú várakozás- } \\
\text { nál }\end{array}$ \\
\hline
\end{tabular}

PSA = prostataspecifikus antigén; $\mathrm{RT}$ = radioterápia 


\begin{tabular}{|c|c|c|c|c|}
\hline Szerző, évszám és ország & Esetszám & Vizsgált időhatár & Túlélési hatás & Megjegyzés \\
\hline $\begin{array}{l}\text { Mahmud, 2006, } \\
\text { Kanada }\end{array}$ & 1592 & $\begin{array}{l}20,46 \text { nap } \\
3 \text { hónap }\end{array}$ & $\begin{array}{l}\text { Nincs, illetve Van, NS, } \\
\mathrm{p}=0,051\end{array}$ & $\begin{array}{l}\text { Hólyagrák; } 3 \text { hónapon túl 20\%-os mortalitásnö- } \\
\text { vekedés }\end{array}$ \\
\hline Fradet, 2006, review & 18 tanulmány & 64 nap & $\operatorname{Nincs}(\operatorname{Van}: 2 / 18)$ & Hólyagrák; ideális esetben mútét 4 héten belül \\
\hline Stec, 2008, USA & 722 & 1, 2 hó & $\operatorname{Nincs}(\mathrm{p}=0,18)$ & Veserák; minden mútét 3 hónapon belül \\
\hline Kim, 2012, Dél-Korea & 1732 & 1 hónap & $\operatorname{Nincs}(\mathrm{p}=0,896, \mathrm{p}=0,737)$ & Veserák; kiújulásmentes túlélés alapján \\
\hline Becker, 2014, Kanada & 6237 & 3 hó & $\operatorname{Nincs}(\mathrm{p}=0,09, \mathrm{HR}: 1,33)$ & $\begin{array}{l}\text { Időskori veserák; daganatspecifikus halálozás } \\
\text { MVA szerint nem érintett }\end{array}$ \\
\hline Mano, 2016, USA & 1278 & 3 hónap & $\operatorname{Van}(\mathrm{HR}: 1,17, \mathrm{p}=0,002)$ & $\begin{array}{l}\text { Veserák; hosszú várakozás gyenge állapotú } \\
\text { betegeknél }\end{array}$ \\
\hline Jewett, 2006, review & 3 tanulmány & Különböző & Nincs & Veserák; várakozási idők különbözői formái \\
\hline Bell, 2006, review & 5 tanulmány & Különböző & $\operatorname{Van}(4 / 5)$ & Hererák; nehezen összevethető adatok \\
\hline
\end{tabular}

MVA = multivariációs analízis; NS = nem szignifikáns

8. táblázat | Nőgyógyászati daganatok ellátásával foglalkozó közlemények

\begin{tabular}{|c|c|c|c|c|}
\hline $\begin{array}{l}\text { Szerző, évszám és } \\
\text { ország }\end{array}$ & Esetszám & Vizsgált idóhatár & Túlélési hatás & Megjegyzés \\
\hline Perri, 2014, Izrael & 321 & 30,45 nap & Nincs, $\mathrm{p}=0,38$ & Méhnyakrák, mindig van idő az ováriumprezervációra \\
\hline $\begin{array}{l}\text { Nanthamongkolkul, } \\
\text { 2015, Thaiföld }\end{array}$ & 441 & 8 hét & $\begin{array}{l}\text { Nincs, } \mathrm{p}=0,677 \\
\operatorname{Van}, \mathrm{HR}: 3,4, \mathrm{p}=0,021\end{array}$ & Méhnyakrák, mütét, időhatás hosszú távú túlélőknél \\
\hline Shen, 2016, Tajvan & 9081 & 4 hó & $\operatorname{Van}, \mathrm{p}<0,05$ & $\begin{array}{l}\text { Méhnyakrák, 2,3l× mortalitásrizikó, késés főleg idős } \\
\text { betegeknél }\end{array}$ \\
\hline $\begin{array}{l}\text { Crawford, 2002, } \\
\text { Skócia }\end{array}$ & 781 & $40,61,92$ nap & $\begin{array}{l}\text { Nincs, inverz, HR: } 0,71 \\
0,47,0,53\end{array}$ & Méhtestrák, súlyosabb esetek korai mútéte \\
\hline
\end{tabular}

\section{Egyéb urológiai tumorok (7. táblázat)}

\section{Hólyagrák}

Mahmud nem talált összefüggést a túlélés és a mútétre várakozás ideje között, de a 3 hónapon túl operált páciensek esetében már 20\%-os mortalitásnövekedést prognosztizált [54].

\section{Veserákok}

Stec 5 éves betegségmentes túlélési adatokat elemezve arra a következtetésre jutott, hogy a hosszabb várakozási idő nem jár a túlélési esély csökkenésével [55]. Kim szerint az 1 hónapon belül vagy azon túl elvégzett operáció nincs hatással sem a kiújulásmentes, sem a daganatspecifikus túlélésre [56]. Becker idős betegeknél univariációs analízis szerint talált, multivariációs analízis szerint már nem talált összefüggést a megkésett mútét és a betegségmentes túlélés között [57]. Mano szerint a mútétre való 3 hónapos várakozás sem befolyásolta károsan a daganatspecifikus túlélés mértékét. Ugyanakkor a teljes túlélési adatokat rontotta az extrém hosszú várakozás, de ilyenkor a hosszabb belgyógyászati előkészítés állt leginkább a több hónapos csúszás hátterében [58].

A kezelés megkezdésének ideje szempontjából a Canadian Journal of Urology valamennyi urológiai daganatos entitást érintő összefoglalókat közölt (6. és 7. táblázat) egy 2006-os számában. Fradet 18 közleményból hólyagdaganatok esetén nem tudott egyértelmú összefüggést találni a sebészi beavatkozás ideje és a túlélési mutatók között, bár a referálástól a mútét idôpontjáig eltelt átlagos idő 64 nap volt [59]. Jewett vesedaganatos betegek mútéti ellátásra kerülését illetően 3 releváns közlemény alapján nem talált egyértelmú statisztikai hatást a mútéti csúszás és a túlélési mutatók között [60]. Bell heretumoros betegek mútéti ellátásának idejét és a túlélési mutatókat elemezte. Öt közleményből négyben észlelt adatokat arra vonatkozóan, hogy a megkésett ellátás a progreszsziómentes és a teljes túlélés romlását okozta, de tekintettel az eltérô definíciókra és a sokszor hiányos adatokra, nem tudott statisztikailag értékelhetô eredményeket felmutatni [61]. Saad prostatatumoros betegeknél 13 tanulmányból 6 esetben talált összefüggést a megcsúszott mútét/kezelés és a PSA-relapsus ideje között. Figyelembe véve a sokszor extrém hosszú várakozási időt is (akár 244 nap), a szerzők nem tudtak egyértelmú statisztikai hatást megállapítani [62].

\section{Nögyógyászati tumorok (8. táblázat)}

Perri méhnyakdaganatos páciensek első ellátása kapcsán nem talált túlélési különbséget, ha a betegek kevesebb, 
mint 30 vagy több, mint 45 napot vártak [63]. Nanthamongkolkul szerint korai méhnyakrákok esetében a várakozási időnek nem volt hatása a teljes túlélésre, de multivariációs analízis során már különbséget észleltek a hosszú távon túlélők esetében [64]. Shen adatbázisából azt állapította meg, hogy a négy hónapon túli terápiaindítás a mortalitás igen komoly növekedésével jár együtt [65]. Crawford mütéttel ellátott méhtesttumoros betegeknél inverz összefüggést talált, miszerint a hosszabb várakozás jobb túléléssel jár együtt. Konklúzióként megállapítja, hogy a súlyosabb esetek mútéti ellátása általában előbbre kerül egy nőgyógyászati-onkológiai osztályon [66].

\section{Többféle daganatos entitással foglalkozó közlemények}

Yun 2012-es munkája során koreai kórházakban mütött 147682 rákbeteg adatait elemezve azt észlelte, hogy a nagyobb kórházakban operált pácienseknek jobbak a túlélési mutatóik. A több, mint egy hónapos várakozás gyomor-, hasnyálmirigy-, vastagbél- és tüdőrák esetében nem hátráltatta a gyógyulási esélyeket, de végbélcarcinoma (HR: 1,28) és emlőrák (HR: 1,59) esetében már a túlélési mutatókat is rontotta [67]. Shin szintén dél-koreai tapasztalatok alapján $(\mathrm{n}=7529)$ vastagbél- és emlőrák esetében a 3 hónapon túli mútéti csúszást illetően túlélési hátrányt jelzett (HR: 2,65 és 1,91), de ezt 3 hónapon belül már nem tudta bizonyítani, továbbá nem talált hasonló összefüggést tüdő- és pajzsmirigyrákok esetében [68]. Az egyetlen, több daganattípust magában foglaló prospektív módon tervezett vizsgálat során Torring 1129 dániai emlő-, tüdő-, prostata- és vastagbélrákos, illetve melanomás beteg kivizsgálása kapcsán megállapította, hogy a betegek kb. 40\%-ánál a megkésett ellátás rizikóval jár, ugyanakkor mind a nagyon korán, mind a későn kezelt páciensek túlélési mutatói rosszabbak voltak [69]. Redaniel több, mint 20 ezer angliai emlő-, tüdő-, prostata- és vastagbélrákos beteg adataiból megállapította, hogy prostatarák esetében tünetektől függetlenül, tüdő- és vastagbélrák esetén, ha a tünetek nem fenyegetőek, a hosszabb kivizsgálás akár túlélési előnnyel (HR: 0,85 , illetve 0,81 ) is járhat [70].

Legvégül mindenképpen külön szükséges értékelni az egyetlen, a jelen munkánkhoz sokban hasonló, szinte valamennyi szervrendszer betegségeit áttekintő összefoglaló tanulságait. Neal 2015-ben tünetes rákbetegeknél a kivizsgálás és a kezelésindítás időfaktorát kutatva összesen 177 közleményt dolgozott fel. Ő azonban nem csak a túlélési hatást vizsgálta, hanem egyéb betegségkimeneteli mutatók (stádiumváltás, életminőség) változásaira vonatkoztatva is szakirodalmi keresést indított. Továbbá nem csak a (diagnózist követő) terápiakezdés időfaktorát kutatta, hanem a kórisméhez jutás (így például a tünetek megjelenése és az orvoshoz fordulás között eltelt időszak) másodlagos hatásait is elemezte. A rendkívül alapos és részletes tanulmány megállapította, hogy az időfaktornak komoly szerepe lehet fej-nyaki tumorok, emlőrák, hererák, (az általunk nem vizsgált) melanoma és colorectalis carcinomák esetében. Konklúzióként hangsúlyozta a daganatok különbözőségét, a korai diagnosztika fontosságát és a további kutatások szükségességét [8].

\section{Megbeszélés}

A daganatos betegség kórisméje vagy csak annak komoly gyanúja szinte sorscsapásszerú érzés minden ember számára. A pszichés sokkot okozó hír újraértékelteti a mindennapokat, és a legtöbb emberben a betegséget legyőzni akarás stratégiája alakul ki. Persze vannak olyanok, akik nem fogadják el a betegség tényét, vagy inkább alternatív módszerekhez fordulnak, de a többség az egészségügyi ellátórendszertől várja a segítséget. Ettől kezdve a betegek jogos igénye az empátia, a szakmaiság és öszszességében a pozitív segítségnyújtó attitüd. Ilyenkor akár 1-2 hét fölöslegesnek látszó várakozás is elviselhetetlennek tûnik, és sokak ekkor szembesülnek az ellátórendszer túlterheltségével. Ilyenkor nehéz azt is megérteni, hogy egy-egy vizsgálat kiértékelése hosszadalmas, vagy hogy mindenképpen szükség van az onkoteammegbeszélésre. Az orvos szemszögéből pedig szakmai (és morális) kérdés az, hogy mi a fontosabb: a kezelés minél korábbi megkezdése, avagy célszerúbb végigvinni az indokolható további diagnosztikus lépéseket.

A daganatos betegségek biológiai viselkedésének megértése régi célja az onkológiai kutatásoknak. Azt például tudjuk, hogy a szolid tumorok többsége hónapok, évek alatt alakul ki a szervezetben. Ehhez a tényhez igazodnak a népegészségügyi szûrőprogramok is. Az is előfordul, hogy egy tumoros kórkép igazolása véletlenszerü egy rutinkivizsgálás során, de sajnos betegeink jelentős része már panaszokkal fordul orvoshoz. A szakirodalom több részre osztja a „várakozási időt”, azaz az első tünetektől az orvoshoz fordulás, illetve a szakorvosi várólista idejét, a diagnózis felállításának hosszát, a diagnózistól a terápiás döntésig tartó időt és az első kezelés megkezdésének idejét különböztethetjük meg [8, 32, 60]. Ebből is látszik, hogy számtalan orvosi és szociális tényező bonyolult rendszeréról van szó. A pszichés tényezóket elemezve Mathews azt találta, hogy a betegek várakozási toleranciáját három fó szempont alakítja: a kezelőorvosok szakmai képzettsége, attitűdje, az egészségügyi ellátórendszer szervezettsége és a kivizsgálás menetének az elvárásokhoz mért időszerüsége, pontossága [71]. Naghavi fej-nyak tumoros betegeknél mérte fel a megkésett kezelésindítás szociológiai hátterét, és megállapította, hogy ez és az előrehaladottabb tumoros státusz összefügg számtalan szociokulturális tényezővel [72]. Mi is több közleményben észleltük a hátrányos pszichoszociális státusz kivizsgálást nehezítő hatását $[9,10,21$, 24]. Ezek a tényezők pedig befolyásolják az orvoshoz fordulás idejét, az együttmúködési készséget és a különböző kezelések fizikai elviselésének képességét is.

Az alapvető dilemmára, a daganatok növekedési mértékére a sejtbiológiai ismeretek sem adnak egyelőre egy- 
értelmű választ, bár régóta kutatott témáról van szó. Egy rákos szövet növekedését számtalan sejtkinetikai, környezeti és immunológiai tényező határozza meg. Talán a legegyszerúbb az úgynevezett duplikációs idő meghatározása: ez felnőttkori szolid daganatok esetében a leggyakrabban 1-3 hónap közé tehető, és általában gyorsabb lágyszöveti tumorok, laphámsejtes carcinomák, mint mirigyrákok esetében $[73,74]$. Wyatt sejtbiológiai számítások alapján azt véleményezte, hogy gyorsan növekvő daganattípusok esetében 1-2 hónapos késlekedés a kezelés megkezdésében a gyógyulás esélyét ronthatja, ugyanakkor lassan növekvő tumoroknál a megkésett ellátás nem jár káros következményekkel [75]. A hagyományos, kiindulási szervet jelölő daganatcsoportosítás azonban nem határozza meg az egyes tumorok várható biológiai viselkedését, azaz például emlőrákok, tüdőrákok, de akár a gliomák is biológiai szempontból rendkívül heterogén betegségkategóriák, igen eltérő klinikai viselkedéssel és prognózissal. Ebből a szempontból talán a legtöbbet vizsgált daganattípus az emlőrák, és éppen magyar kutatók írták le, hogy az egyes szövettani-genetikai alcsoportok valószínúségben és időben is igen különböző metasztatikus potenciállal bírnak, amely egyúttal igen különböző túlélési esélyeket is jelent [76]. Tehát elképzelhető, hogy külön kellene vizsgálni az egyes szövettani altípusokat, mert bizonyos esetekben valóban rendkívül fontos a gyors kivizsgálás és terápiaindítás. Ezt bizonyíthatja, hogy az általunk elemzett közlemények közül a fiatalkori (és szinte bizonyosan agresszívebb viselkedésű) emlőrákok esetében lehetett például kimondani, hogy 1-2 hetes késlekedés is komoly következményekkel járhat [10]. Egyébiránt a szövettani altípus, gradus vagy a „biológiai rizikócsoportok” meghatározó szerepére több közlemény is utal $[51,53]$.

Az utóbbi gondolatnak egy másfajta megközelítése lehet az a klinikai megfigyelés, miszerint bizonyos betegségállapotok esetén elfogadható alternatíva lehet a beteg szoros obszervációja, amit az angol nyelvű szakirodalom „watchful waiting” vagy „wait and see” kifejezésekkel illet. Közismert, hogy bizonyos utókezeléseket így mellőzni lehet, de néha ezt a stratégiát választhatjuk fennálló daganatos betegség esetén is. Erre lehet példa az alacsony rizikójú prostataráknál választható szoros követés, de ezt az álláspontot képviseljük nehezen tolerálható és minimális terápiás haszonnal járó ellátások esetén is. Érdekes Pickering 2015-ös összefoglalója: ez a közlemény azt taglalja, hogy nem tünetes áttétes vesedaganat esetén előnyös lehet a szoros obszerváció, hiszen így elkerülhetjük a mellékhatásokat, és ugyanakkor nem csökken a későbbi terápia effektusa [77].

Számtalan vizsgálat jelzett fordított időfaktor-effektust, azaz a korábban kezelt betegek túlélési esélyei roszszabbak voltak [29, 31, 43, 66]. Comber összefoglalójában szintén arra a következtetésre jutott, hogy az előrehaladottabb, tünetes kórképek sokszor előbb kerülnek ellátásra, és értelemszerüen rosszabb a prognózisuk, ugyanakkor a kevésbé előrehaladott, jobban gyógyítható daganatok sokszor később jutnak kezeléshez. Így a szerzôk a korai ellátás paradox hatására hívták fel a figyelmet [78]. Persze ez azt is jelenti, hogy a súlyosabb esetek korai ellátásával az időfaktor valós szerepe nem jelenik meg a statisztikákban. A másik oldalról tekintve pedig azt is több szerző jelezte, hogy a komolyabb kísérő betegségekkel jellemzett betegek mütéte, kezelése csúszott, és így nem meglepetés a késés élettartamot csökkentő hatása [33, 58, 65].

A jelen munkánkban összesen 67 közlemény eredményeit összegeztük. A munkák döntő része 4-8 hetes időtartamot határozott meg számolási határnak, de néhány esetben a kezelés megkezdése akár több hónapra is megcsúszott. Az egyes daganatféleségeket csoportokra bontva a következő következtetéseket lehet levonni: az emlőrák elsődleges ellátását illetően mindenképpen veszélyeztetett csoportnak tekinthetők a fiatal betegek és az előrehaladott betegséggel orvoshoz fordulók. Malignus gliomák ellátása esetében érdekes módon nem mondhatjuk ki a negatív időfaktori hatást, pedig ez a betegségtípus köztudottan a gyorsan progrediáló daganatok közé tartozik. Tüdőrák esetében csak 1-2 munka jelez negatív túlélési hatást, igaz, itt a legnagyobb betegszámú áttekintésekről van szó. Fej-nyaki tumoroknál már egyértelmú a helyzet, 1-2 hónapos időintervallumokat vizsgálva a megkésés szignifikáns mértékú túlélés-rosszabbodást okoz. Ugyanakkor a közlemények hangsúlyozzák a betegek sokszor igen rossz szociális hátterét. Gastrointestinalis tumoroknál érdekes módon csak néhány, colorectalis carcinomák ellátásával foglalkozó tanulmány jelezte a késéssel kapcsolatos negatív élettartami hatást. Prostatarák esetén a legtöbb szerző hangsúlyozza a különböző rizikócsoportok várhatóan különböző viselkedését. Hólyagrák esetében felmerülhet, veserák esetében kevésbé a mútéti késlekedés túlélési következménye, a hererákkal foglalkozó összefoglaló azonban egyértelmú, de nehezen számszerüsíthető gyógyulási hátrányt valószínűsít. Nőgyógyászati daganatok esetén több vizsgálat állapított meg várakozás okozta negatív túlélési hatást, főleg előrehaladott eseteket érintve. Összegezve a fentieket, hangsúlyozni szükséges, hogy azon közleményekben, ahol az elhúzódó kivizsgálás negatív hatásúnak bizonyult, legalább 1-2 hónapos várakozásról volt szó. Kivétel például a már említett fiatalkori emlőrákok esete, ahol akár 2 hetes időtöbblet is ronthatja a gyógyulási esélyeket [10]. Azt azonban még egyszer ki kell emelni, hogy a leggyakoribb felnőttkori szolid tumorokat vizsgáltuk, leukaemiák, gyermekkori daganatok, sőt például kissejtes tüdőrák esetében nyilván más dinamikájú betegségekről, más időfaktorhatásról lehet szó.

\section{Következtetés}

Irodalmi kutatómunkánk összesítése alapján a fej-nyaki tumorok, a fiatalkori emlőrák és a hererák esetében mondható ki egyértelmúen, hogy a kezelésre való hosszú várakozás negatív hatású a túlélési esélyek vonatkozásá- 
ban. Ezen túlmenően végbél-, méhnyak- és tüdőrák esetében merülhet még fel leginkább az időfaktor bizonyos prognosztikai szerepe. Azt azonban hangsúlyozni kell, hogy az egyes eltérő biológiai viselkedésű betegségalcsoportok egészen más megközelítést igényelnek a sürgősség szempontjából is. A kérdés teljes megválaszolása azonban még sok, módszertani nehézséggel is járó kutatómunkát igényel Magyarországon is. Végül az is kimondható, hogy felnőttkori szolid tumoroknál a beteg és a betegség biológiai tulajdonságaira is alapozva az „egyénre szabott”, optimális kezelés kiválasztása a hoszszú távú túlélés biztosításának legfontosabb záloga. Mindazonáltal orvosi kötelességünk, hogy betegeink kivizsgálását is próbáljuk optimalizálni és az ellátást minél korábban, lehetóleg a diagnózistól számított 30 napon belül megkezdeni. A fenti kutatómunka alapján azonban azt mindenképpen hangsúlyozni kell, hogy néhány napos és indokolható késlekedés a kezelés megindítása előtt semmiképpen sem lehet végzetes. Mindez pedig fontos üzenet mind az orvosoknak, mind betegeinknek.

Anyagi támogatás: A szerzők a közlemény megírása kapcsán anyagi támogatásban nem részesültek.

Szerzői munkamegosztás: M. L.: Az elsődleges hipotézis kidolgozása, adatgyűjtés, a közlemény megírása. T. T.: A biológiai-patológiai hipotézis kidolgozása, adatgyújtés. Z. A.: Statisztikai véleményezés, a jövőbeli feladatok kidolgozása. B. I.: Összegzố véleményezés, a munkahipotézis ellenőrzése. A cikk végleges változatát valamennyi szerző elolvasta és jóváhagyta.

\section{Érdekeltségek: A szerzőknek nincsenek érdekeltségeik.}

\section{Köszönetnyilvánítás}

Ezúton köszönjük meg $D r$. Kaló Zoltán (Eötvös Loránd Tudományegyetem, Társadalomtudományi Kar), Dr. Torday László (Szegedi Tudományegyetem, Onkoterápiás Klinika) és Dr. Pécsi Balázs (Pécsi Tudományegyetem, Klinikai Központ, Onkoterápiás Intézet) szakmai ötleteit, tanácsait a dolgozatírás kapcsán.

\section{Irodalom}

[1] Decree No. 124/2015 (V. 26.) of the Hungarian Government about the modification of the former Government decree No. 43/1999 (III. 3.) on the "Detailed rules of financing healthcare services from the Health Insurance Fund". [124/2015. (V. 26.) Korm. rendelet az egészségügyi szolgáltatások Egészségbiztosítási Alapból történő finanszírozásának részletes szabályairól szóló 43/1999. (III. 3.) Korm. rendelet módosításáról.] Magyar Közlöny 2015; 71: 6432. [Hungarian]

[2] Moizs M, Ruzsa A, Repa I, et al. Management of cancer patient route in practice. [Onkológiai betegút menedzselés gyakorlati megvalósítása.] IME 2015; 14: 50-54. [Hungarian]

[3] Kásler M, Ottó S, Kenessey I. The current situation of cancer morbidity and mortality in the light of the National Cancer Registry. [A rákmorbiditás és -mortalitás jelenlegi helyzete a Nemzeti Rákregiszter tükrében.] Orv Hetil. 2017; 158: 84-89. [Hungarian]
[4] Mangel L, Kövér E, Szilágyi I, et al. Novel quality assurance method in oncology: the two-level, multi-disciplinary and oncotherapy oncology team system. [Új típusú minóségbiztosítás az onkológiában: a kétlépcsős (multidiszciplináris és onkoterápiás) onkoteamrendszer.] Orv Hetil. 2012; 153: 1984-1991. [Hungarian]

[5] Chen Z, King W, Pearcey R, et al. The relationship between waiting time for radiotherapy and clinical outcomes: a systematic review of the literature. Radiother Oncol. 2008; 87: 3-16.

[6] Biagi JJ, Raphael MJ, Mackillop WJ, et al. Association between time to initiation of adjuvant chemotherapy and survival in colorectal cancer: a systematic review and meta-analysis. JAMA 2011; 305: 2335-2342.

[7] Raphael MJ, Biagi JJ, Kong W, et al. The relationship between time to initiation of adjuvant chemotherapy and survival in breast cancer: a systematic review and meta-analysis. Breast Cancer Res Treat. 2016; 160: 17-28.

[8] Neal RD, Tharmanathan P, France B, et al. Is increased time to diagnosis and treatment in symptomatic cancer associated with poorer outcomes? Systematic review. Br J Cancer 2015; 112: S92-S107.

[9] McLaughlin JM, Anderson RT, Ferketich AK, et al. Effect on survival of longer intervals between confirmed diagnosis and treatment initiation among low-income women with breast cancer. J Clin Oncol. 2012; 30: 4493-4500.

[10] Smith EC, Ziogas A, Anton-Culver H. Delay in surgical treatment and survival after breast cancer diagnosis in young women by race/ethnicity. JAMA Surg. 2013; 148: 516-523.

[11] Redaniel MT, Martin RM, Cawthorn S, et al. The association of waiting times from diagnosis to surgery with survival in women with localised breast cancer in England. Br J Cancer 2013; 109: 42-49.

[12] Eastman A, Tammaro Y, Moldrem A, et al. Outcomes of delays in time to treatment in triple negative breast cancer. Ann Surg Oncol. 2013; 20: 1880-1885.

[13] Brandão Souza C, Fustinoni SM, Amorim MH, et al. Breast cancer: diagnosis-to-treatment waiting times for elderly women at a reference hospital of São Paulo, Brazil. Cien Saude Colet. 2015; 20: 3805-3816.

[14] Shandiz FH, Janghorban R, Azarkish F, et al. Effect of treatment delay on survival in patients with breast cancer. Online J Health Allied Sci. 2016; 15: 1-4.

[15] Lai R, Hershman DL, Doan T, et al. The timing of cranial radiation in elderly patients with newly diagnosed glioblastoma multiforme. Neuro Oncol. 2010; 12: 190-198.

[16] Gliński B, Urbański J, Hetnał M, et al. Prognostic value of the interval from surgery to initiation of radiation therapy in correlation with some histo-clinical parameters in patients with malignant supratentorial gliomas. Contemp Oncol (Pozn). 2012; 16: 34-37.

[17] Seidlitz A, Siepmann T, Löck S, et al. Impact of waiting time after surgery and overall time of postoperative radiochemotherapy on treatment outcome in glioblastoma multiforme. Radiat Oncol. 2015; 10: 172

[18] Loureiro LV, Victor Eda S, Callegaro-Filho D, et al. Minimizing the uncertainties regarding the effects of delaying radiotherapy for glioblastoma: A systematic review and meta-analysis. Radiother Oncol. 2016; 118: 1-8.

[19] Fortin A, Bairati I, Albert M, et al. Effect of treatment delay on outcome of patients with early-stage head-and-neck carcinoma receiving radical radiotherapy. Int J Radiat Oncol Biol Phys. 2002; 52: 929-936.

[20] Caudell JJ, Locher JL, Bonner JA. Diagnosis-to-treatment interval and control of locoregionally advanced head and neck cancer. Arch Otolaryngol Head Neck Surg. 2011; 137: 282-285.

[21] van Harten MC, Hoebers FJ, Kross KW, et al. Determinants of treatment waiting times for head and neck cancer in the Nether- 
lands and their relation to survival. Oral Oncol. 2015; 51: 272 278.

[22] van Harten MC, de Ridder M, Hamming-Vrieze O, et al. The association of treatment delay and prognosis in head and neck squamous cell carcinoma (HNSCC) patients in a Dutch comprehensive cancer center. Oral Oncol. 2014; 50: 282-290.

[23] Murphy CT, Galloway TJ, Handorf EA, et al. Survival impact of increasing time to treatment initiation for patients with head and neck cancer in the United States. J Clin Oncol. 2016; 34: 169178 .

[24] Sharma S, Bekelman J, Lin A, et al. Clinical impact of prolonged diagnosis to treatment interval (DTI) among patients with oropharyngeal squamous cell carcinoma. Oral Oncol. 2016; 56: $17-24$.

[25] Liao CT, Chen HN, Wen YW, et al. Association between the diagnosis-to-treatment interval and overall survival in Taiwanese patients with oral cavity squamous cell carcinoma. Eur J Cancer 2017; 72: 226-234

[26] Cheraghlou S, Kuo P, Judson BL. Treatment delay and facility case volume are associated with survival in early-stage glottic cancer. Laryngoscope 2017; 127: 616-622.

[27] Polesel J, Furlan C, Birri S, et al. The impact of time to treatment initiation on survival from head and neck cancer in north-eastern Italy. Oral Oncol. 2017; 67: 175-182.

[28] Liang H, Xiang, YQ, Lv X, et al. Survival impact of waiting time for radical radiotherapy in nasopharyngeal carcinoma: A large institution-based cohort study from an endemic area. Eur J Cancer 2017; 73: 48-60

[29] Myrdal G, Lambe M, Hillerdal G, et al. Effect of delays on prognosis in patients with non-small cell lung cancer. Thorax 2004; 59: 45-49.

[30] Yorio JT, Xie Y, Yan J, et al. Lung cancer diagnostic and treatment intervals in the United States: a health care disparity? J Thorac Oncol. 2009; 4: 1322-1330.

[31] Diaconescu R, Lafond C, Whittom R. Treatment delays in nonsmall cell lung cancer and their prognostic implications. J Thorac Oncol. 2011; 6: 1254-1259.

[32] Radzikowska E, Roszkowski-Śliż K, Głaz P. The impact of timeliness of care on survival in non-small cell lung cancer patients. Pneumonol Alergol Pol. 2012; 80: 422-429.

[33] Samson P, Patel A, Garrett T, et al. Effects of delayed surgical resection on short-term and long-term outcomes in clinical stage I non-small cell lung cancer. Ann Thorac Surg. 2015; 99: $1906-$ 1913.

[34] Gomez DR, Liao KP, Swisher SG, et al. Time to treatment as a quality metric in lung cancer: Staging studies, time to treatment, and patient survival. Radiother Oncol. 2015; 115: 257-263.

[35] Vinod SK, Chandra A, Berthelsen A, et al. Does timeliness of care in non-small cell lung cancer impact on survival? Lung Cancer 2017 ; 112: 16-24.

[36] Visser E, Leeftink AG, van Rossum PS, et al. Waiting time from diagnosis to treatment has no impact on survival in patients with esophageal cancer. Ann Surg Oncol. 2016; 23: 2679-2689.

[37] Visser E, van Rossum PS, Leeftink AG, et al. Impact of diagnosisto-treatment waiting time on survival in esophageal cancer patients - A population-based study in The Netherlands. Eur J Surg Oncol. 2016; 16: 30956-30958.

[38] Brenkman HJ, Visser E, van Rossum PS, et al. Association between waiting time from diagnosis to treatment and survival in patients with curable gastric cancer: A population-based study in the Netherlands. Ann Surg Oncol. 2017; 24: 1761-1769.

[39] Raptis DA, Fessas C, Belasyse-Smith P, et al. Clinical presentation and waiting time targets do not affect prognosis in patients with pancreatic cancer. Surgeon 2010; 8: 239-246.

[40] Amr B, Shahtahmassebi G, Briggs, CD, et al. Assessment of the effect of interval from presentation to surgery on outcome in patients with peri-ampullary malignancy. HPB (Oxford) 2016 ; 18: 354-359.
[41] Gort M, Otter R, Plukker T, et al. Actionable indicators for short and long term outcomes in rectal cancer. Eur J Cancer 2010; 46: 1808-1814.

[42] Helewa RM, Turner D, Park J, et al. Longer waiting times for patients undergoing colorectal cancer surgery are not associated with decreased survival. J Surg Oncol. 2013; 108: 378-384.

[43] Amri R, Bordeianou LG, Sylla P, et al. Treatment delay in surgically-treated colon cancer: does it affect outcomes? Ann Surg Oncol. 2014; 21: 3909-3916.

[44] Redaniel MT, Blazeby JM, et al. The association of time between diagnosis and major resection with poorer colorectal cancer survival: a retrospective cohort study. BMC Cancer 2014; 14: 642 .

[45] Murchie P, Raja EA, Brewster DH, et al. Time from first presentation in primary care to treatment of symptomatic colorectal cancer: effect on disease stage and survival. Br J Cancer 2014; 111: 461-469.

[46] Nguyen PL, Whittington R, Koo S, et al. The impact of a delay in initiating radiation therapy on prostate-specific antigen outcome for patients with clinically localized prostate carcinoma. Cancer 2005; 103: 2053-2059.

[47] Graefen M, Walz J, Chun KH, et al. Reasonable delay of surgical treatment in men with localized prostate cancer impact on prognosis? Eur Urol. 2005; 47: 756-760.

[48] Andrews SF, Horwitz EM, Feigenberg SJ, et al. Does a delay in external beam radiation therapy after tissue diagnosis affect outcome for men with prostate carcinoma? Cancer 2005; 104: 299304.

[49] O'Brien D, Loeb S, Carvalhal GF, et al. Delay of surgery in men with low risk prostate cancer. J Urol. 2011; 185: 2143-2147.

[50] Korets R, Seager CM, Pitman MS, et al. Effect of delaying surgery on radical prostatectomy outcomes: a contemporary analysis. BJU Int. 2012; 110: 211-216.

[51] van den Bergh RC, Albertsen PC, Bangma CH, et al. Timing of curative treatment for prostate cancer: a systematic review. Eur Urol. 2013; 64: 204-215.

[52] Redaniel MT, Martin RM, Gillatt D, et al. Time from diagnosis to surgery and prostate cancer survival: a retrospective cohort study. BMC Cancer 2013; 13: 559.

[53] O'Callaghan ME, Shi Z, Kopsaftis T, et al. Prostate cancer outcomes and delays in care. Int Urol Nephrol. 2017; 49: 449-455.

[54] Mahmud SM, Fong B, Fahmy N, et al. Effect of preoperative delay on survival in patients with bladder cancer undergoing cystectomy in Quebec: a population based study. J Urol. 2006; 175 : $78-83$.

[55] Stec AA, Coons, BJ, Chang SS, et al. Waiting time from initial urological consultation to nephrectomy for renal cell carcinoma - does it affect survival? J Urol. 2008; 179: 2152-2157.

[56] Kim KH, You D, Jeong IG, et al. The impact of delaying radical nephrectomy for stage II or higher renal cell carcinoma. J Cancer Res Clin Oncol. 2012; 138: 1561-1567.

[57] Becker A, Roghmann F, Ravi P, et al. Delay in nephrectomy and cancer control outcomes in elderly patients with small renal masses. Urol Int. 2014; 92: 455-461.

[58] Mano R, Vertosick EA, Hakimi AA, et al. The effect of delaying nephrectomy on oncologic outcomes in patients with renal tumors greater than $4 \mathrm{~cm}$. Urol Oncol. 2016; 34: 239.el-239.e8.

[59] Fradet Y, Aprikian A, Dranitsaris G, et al. Does prolonging the time to bladder cancer surgery affect long-term cancer control: a systematic review of the literature. Can J Urol. 2006; 13(Suppl 3): $37-47$.

[60] Jewett M, Rendon R, Dranitsaris G, et al. Does prolonging the time to renal cancer surgery affect long-term cancer control: a systematic review of the literature. Can J Urol. 2006; 13 (Suppl 3): 54-61.

[61] Bell D, Morash C, Dranitsaris G, et al. Does prolonging the time to testicular cancer surgery impact long-term cancer control: a systematic review of the literature. Can J Urol. 2006; 13(Suppl 3) $30-36$ 
[62] Saad F, Finelli A, Dranitsaris G, et al. Does prolonging the time to prostate cancer surgery impact long-term cancer control: a systematic review of the literature. Can J Urol. 2006; 13(Suppl 3): 16-24.

[63] Perri T, Issakov G, Ben-Baruch G, et al. Effect of treatment delay on survival in patients with cervical cancer: a historical cohort study. Int J Gynecol Cancer 2014; 24: 1326-1332.

[64] Nanthamongkolkul K, Hanprasertpong J. Longer waiting times for early stage cervical cancer patients undergoing radical hysterectomy are associated with diminished long-term overall survival. J Gynecol Oncol. 2015; 26: 262-269.

[65] Shen SC, Hung YC, Kung PT, et al. Factors involved in the delay of treatment initiation for cervical cancer patients: A nationwide population-based study. Medicine (Baltimore) 2016; 95: e4568.

[66] Crawford SC, Davis JA, Siddiqui NA, et al. The waiting time paradox: population based retrospective study of treatment delay and survival of women with endometrial cancer in Scotland. BMJ 2002; 325: 196.

[67] Yun YH, Kim YA, Min YH, et al. The influence of hospital volume and surgical treatment delay on long-term survival after cancer surgery. Ann Oncol. 2012; 23: 2731-2737.

[68] Shin DW, Cho J, Kim SY, et al. Delay to curative surgery greater than 12 weeks is associated with increased mortality in patients with colorectal and breast cancer but not lung or thyroid cancer. Ann Surg Oncol. 2013; 20: 2468-2476.

[69] Torring ML, Frydenberg M, Hansen RP, et al. Evidence of increasing mortality with longer diagnostic intervals for five common cancers: a cohort study in primary care. Eur J Cancer 2013; 49: 2187-2198.

[70] Redaniel MT, Martin RM, Ridd MJ et al. Diagnostic intervals and its association with breast, prostate, lung and colorectal can- cer survival in England: historical cohort study using the Clinical Practice Research Datalink. PLoS ONE 2015; 10: e0126608.

[71] Mathews M, Ryan D, Bulman D. What does satisfaction with wait times mean to cancer patients? BMC Cancer 2015; 15: 1017.

[72] Naghavi AO, Echevarria MI, Strom TJ, et al. Treatment delays, race, and outcomes in head and neck cancer. Cancer Epidemiol. 2016; 45: 18-25.

[73] Krokowski E. Duplication time of malignant tumors - Its value for cancer control. Wien Klin Wochenschr. 1965; 77: 258-259.

[74] Tubiana M. Tumor cell proliferation kinetics and tumor growth rate. Acta Oncol. 1989; 28: 113-121.

[75] Wyatt RM, Beddoe AH, Dale RG. The effects of delays in radiotherapy treatment on tumour control. Phys Med Biol. 2003; 48: $139-155$.

[76] Molnár IA, Molnár BÁ, Vízkeleti L, et al. Breast carcinoma subtypes show different patterns of metastatic behaviour. Virchows Arch. 2017; 470: 275-283.

[77] Pickering LM, Mahgoub MO, Mukherji D. Is observation a valid strategy in metastatic renal cell carcinoma? Curr Opin Urol. 2015; 25: 390-394.

[78] Comber H, Cronin DP, Deady S, et al. Delays in treatment in the cancer services: impact on cancer stage and survival. Ir Med J. 2005; 98: 238-239.

\section{NOTA \\ Új fejlesztés az egészségügyben dolgozók, tanulók részére!}

\section{A magyar nyelvử szakirodalmi keresőszolgáltatás}

Mi a NOTA?
Napivizit Orvosi Tudástár Alkalmazás
Mit tud a NOTA portál?
$\begin{aligned} & \text { Megkönnyíti a magyar nyelvű } \\ & \text { szakirodalmi források keresését. }\end{aligned}$
$\begin{aligned} & \text { Eszköztől függetlenül, akár } \\ & \text { okostelefonnól, a betegágy mellett } \\ & \text { állva is használható. }\end{aligned}$

\section{Miben kereshet a NOTA-val?}

Az Akadémiai Kiadó folyóirataiban: Orvosi Hetilap, Magyar Sebészet, Mentálhigiéné és Pszichoszomatika.

Más kiadók magyar nyelvú szakfolyóirataiban: pl. Lege Artis Medicinae, Hypertonia és Nephrologia, Ideggyógyászati Szemle.

A hatályos szakmai irányelvekben.

Magyar nyelvű kérdésekre adott ango nyelvű találatokban, a PubMeden.
(Mangel László dr., Pécs, Édesanyák útja 17., 7624 e-mail: mangellaszlo@gmail.com)

\section{nota.hu}

\section{Akadémiai Kiadó}

A Wolters Kluwer Csoport tagja

1117 Budapest, Prielle Kornélia u. 21-35. / Telefon: (1) 464-8246 www.akademiai.hu / www.akademiai.com

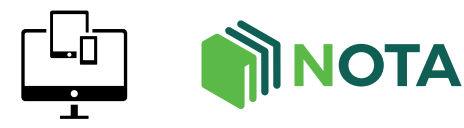

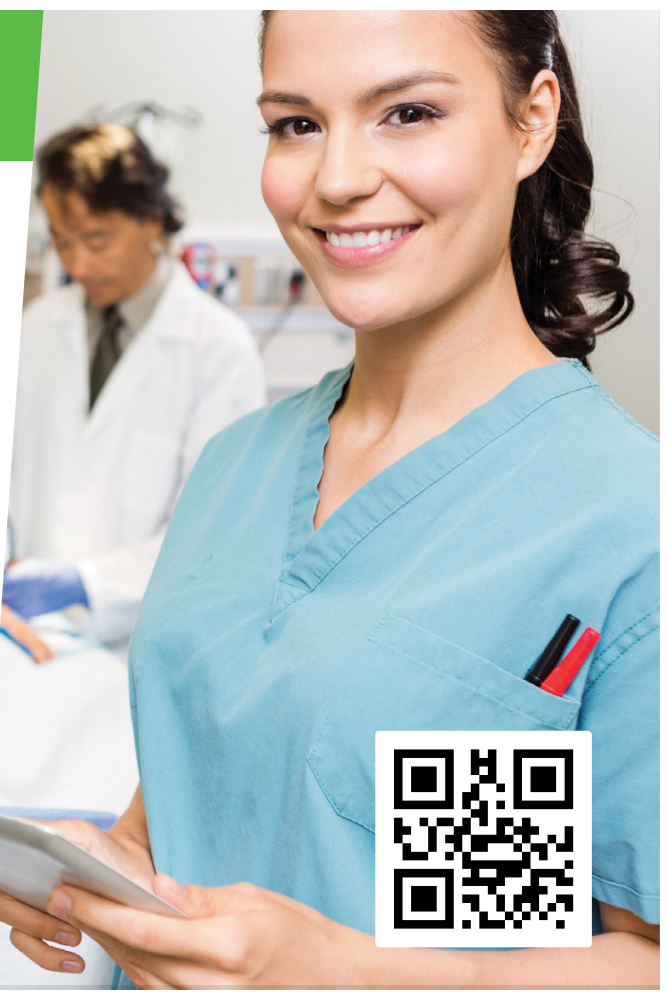

AKADÉMIAI KIADÓ 